\title{
THE QU'APPELLE VALLEY
}

Clarissa Stewart and M. W. Lawson, Fairy Hill

$\mathbf{T}$ HE QU'APPELLE VALLEY, which runS like a large crooked flat-bottomed ditch from where it begins near the South Saskatchewan, passes about twenty-five miles north of Regina on its easterly way to where its little winding river empties into the Assiniboine.

Its flora and fauna contrast sharply with the prairie. Many kinds of trees clothe the wooded ravines that climb through the sharply rising hills to the plain above. Many varieties are not found on the parklands of the north. Elms with their waving plumes, clumps of Manitoba Mapjles, Black Ash both in ravines and on the slopes, abound in many districts. White and Black Poplar or Balm o: Gilead and White Birch may be found where they have not been cut for domestic uses.

Lesser shrubs of many varieties are to be seen: Dogwood, Red Willow, and Golden Willow fringing the river, many sorts of wild fruits, Saskatoons, Chokecherries, Pincherries, $\mathrm{H}$ i g h Bush Cranberries with their exquisite white blossoms, Black Currants and Gooseberries which put forth their tiny green leaves and pale yellow blossoms, the first harbingers of spring, and even Raspberries in favorable seasons, all add to the charm of "the Valley" in blossom and fruitage.

Both ravines and hills are flowerdecked from early spring when the tiny White Phlox appears among the dray grass and the Mauve Anemone, popularly known as the Crocus, appears like a shimmering veil of purple on hillsides, till the Michaelmas Daisy and the Sunflowers are nipped by October frost. Blue, purple, white and yellow Violets suddenly make themselves known, the blue one in damp spots, yellow on sunny hillside and white Johnny-jump-ups in woody ravines. In spring also bloom the gay Yellow Vetches or Wild Sweet Peas, and rarer, Wild Valley Lilies. Later .white, cream, and purple Vetches and the dainty three-flowered Aven brighten the hillsides. In secluded bluffs may be found blue Pea-Vine, another Vetch, and the fluffy Wild Clematis. Wild Roses spring up everywhere, and
Wild Honeysuckle twines around the fruit trees. With midsummer appears our emblem flower the Orange Lily, the Coneflower, yellow or maroon like short-skirted dancers, Black-eyed Susans, Blue Bells, Blueeyed Grass, and Gentians. Then Wild Flax and Meadow Rue, Yarrow, and the gay Willow Herb mark summer's passing. Various kinds of Daisies and Sunflowers appear in late summer with graceful pink-blossomed Wild Buckwheat and occasionally a bank of Wild Blue Hyacinths turning purplish as they fade. Mlany years ago I picked and pressed over one hundred varieties of wild flowers in the Fairy Hill neighborhood. My co-worker on this effort had a most beautiful garden of tame and wild. blooms.

The valley bottom is absolutely flat and covered with Thatch Grass, and often in spring from bank to bank with the flooded river. The hillsides are dotted with stones of many colors; among these grow and bloom varieties of cacti, one kind with magenta blossoms, which later bears edible berries, the other with waxy yellow rose-like blooms. The flooded meadows are a paradise for watertowl: Geese, Ducks, Plovers, Bitterns, Swans, Herons, Coats and Pelicans frequent the meadows.

Land birds are more numerous than we can name. From the Redpolls, Chickadees, Blue Jays, Canada Jays, Woodpeckers, Grosbeaks, Ravens, Waxwings, etc., in winter, to the long procession of spring and summer denizens; the early IVIountain Blue Bird and Clows which divide the honours of early arrival, the cheery Robin, the Baltimore Oriole, the Meadow Lark, to the little Yellow Warbler, the Goldfinch, Catbird, Bobolink, Brown Thresher, Yellow-breasted Chat, Vireos, Wrens, all the numerous family of Sparrows whose most charming members, the White-throated and White-crowned Sparrows appear with the last traces of snow. It would be impossible to name them all. In rainy seasons the Cuckoo may be heard calling from thick bluffs. Hawks and Owls of (Continued on Page 13) 
M.G.S. B.M.

Palm Warbler

15

Water-thrush

Connecticut Warbler

Mourning Warbler

Wilson's Warbler

Redstart

Brewer's Blackbird

Red-winged Blackbird

Baltimore Oriole

Cowbird

Evening Grosbeak

Purple Finch

Hoary Redpoll

\section{5}

.......

1

.......

4

4

5

13

6

3

\section{Mrs. Edith Orman}

We are pleased to have received again from Mrs. Edith Orman, teacher at Walton School, gift renewals to twelve of her students in the Stoughton district. This is the third successive year that Mrs. Orman has done this in order that each family in her district may have the "Blue Jay" in the home. It has been for this reason that her daughter, Constance Orman, has been listed among the Patrons for 1953.

\section{QU'APPELLE VALLEY}

(Continued from Page 11)

different kinds make their home here and many Woodpeckers, and the tiny Hummingbird.

Many animals may still be seen by the observant. Herds of Deer in some seasons, at times single graceful Whitetails bound across the meadow. Lynx have rarely been seen, also Red Foxes, Porcupines, Woodchucks, badgers and coyotes in deep dens in the ravines. Buffalo wallows still show where those noble animals frequented the many springs.

Turtles are found near the river, and the small Newts and colorful Garter Snakes have not all been exterminated. Gophers, plain and stripped, red and grey Squirrels and tiny Chipmunks still make their homes here.

We have made our homes here for over forty years, and have noted these things and many others in our beloved valley, once a place where bands of horses were herded, now more given over to cattle raising.

M.G.S. B.MI.

$\begin{array}{lrr}\text { Common Redpoll .................... } & 313 & 563 \\ \text { Pine Siskin ..................................... } 17 & 99\end{array}$

American Goldfinch ................ 3

Savannah Sparrow ......................... 36

Vesper Sparrow ................................... 32

Slate-colored Junco ................. $338 \quad 335$

Tree Sparrow ................................. 846

Chipping Sparrow ..................... $33 \quad 23$

Clay-colored Sparrow ............. $11 \quad 106$

Harris's Sparrow ......................... 11 5

Gambel's Sparrow ...................... 616

1 White-throated Sparrow..... $49 \quad 40$

Fox Sparrow .................................... 5

Lincoln Sparrow ................................. 95

Swamp Sparrow ................................ 16

Song Sparrow .................................. $7 \quad 79$

Total Individuals ...................1837 1628

Total Species ............................ $60 \quad 45$

Grand Total Species .......................... 79

Grand Total Individuals ...............3465

\section{VISITORS}

By Dora Bardal, Wynyard

There is a lot of bush around here and consequently some of the birds that do not linger on the bald prairie are quite common. We haven't seen Blue Jays for several years, but they used to nest here. Perhaps that is because the Magpies are so numerous now!

Two years ago in the fall, just before the Bluebirds left us and after the snow came, we saw a solitary Bluebird with a rust colored breast. Would that be the Arkansas Bluebird? (It probably was an Eastern Bluebird, which appear in Manitoba, and rarely in Saskatchewan. "A famous writer has described the Eastern Bluebird as 'The sky above, the earth beneath' referring to blue back and red breast. Following this figure of speech, the Mountain Bluebird is purely celestial with no earthly contamination." - Taverner. Ed.)

We have seen flocks of Golden Plovers, and once, several years ago, a flock of Starlings. During the past winter Grosbeaks were common, feeding on the dried-up Saskatoon and Chokecherry berries. We recently have had a Canada Jay with us. Some winters we do not see them at all. 